УДК 182:21-8

Шкуропат Марина, кандидат філологічних наук, доцент, доцент кафедри англійської філології та перекладу Горлівський інститут іноземних мов ДВНЗ «Донбаського державного педагогічного університету»

\title{
ОПОВІДЬ ІЗ ТОЧКОЮ ЗОРУ, ЩО ПОСТІЙНО ЗМІНЮЕТЬСЯ В РОМАНІ ЖАУМЕ КАБРЕ «Я СПОВІДУЮСЯ»
}

У статті розглянуто особливості композииї оповіді в романі Жауме Кабре «Я сповідуюся». Виявлено, що у творі перемикаються типи оповіді від першої та третьої особи й перемежовуються з доволі незвичним типом оповіді з точки зору від другої особи. Дві основні оповідні лінії інтегровані одна з іншою в такий спосіб, щзо важко відчути межі сплетіння. Композицію оповіді побудовано за принципом нерівномірного чергування точок зору, чим відтворюється відповідне світосприйняття головного героя. У тексті співіснують фрагменти з переважанням однорідної оповіді від третьої особи або першої особи із фрагментами, у яких відбувається чергування оповідної точки зору в межах одного абзаиу. Коливання між точками зору дозволяе авторові міџніше контролювати емочійну реакиію читача та створює дуже специфічний стилістичний ефект.

Ключові слова: оповідь від першої особи, оповідь від третьої особи, оповідна точка зору від другої особи», «ти-точка зору».

Mingling points of view in the novel by Jaume Cabre "Confessions.

The article deals with the features of the narrative composition in Jaume Cabré's novel "I Confess». It is revealed that the types of narration from the first and the third person are switched and alternated with a rather unusual type of narration from the second person point of view. The two main narrative lines are integrated with each other so that it is difficult to identify the boundaries within the texture. The composition 
of the narrative, which displays the corresponding world view of the protagonist, is based on the principle of asymmetric distribution of inserts. We can observe coexistence of the fragments with a predominantly homogeneous type of narrative from the third or first person with fragments in which there is an alternation of the narrative point of view within one paragraph. The oscillation between points of view allows the author to more closely control the emotional reaction of the reader and creates a very specific stylistic effect.

Key words: first person narration, third person narration, second person point of view, mingling narration, «you»-point of view.

У світовій літературі існує багато прикладів, коли автори обирають не один тип оповіді, від першої чи третьої особи, а весь час чергують типи оповіді для створення особливого стилістичного й емоційного ефекту. Зміна першої особи на третю часто пов'язана зі зміною точки зору, із прагненням надати більш об'єктивного звучання важливим подієвим епізодам.

Рідко, але приклади не є поодинокими, автори використовують так звану «оповідь від другої особи», або точніше «оповідь із точки зору другої особи». «Оповіддю 3 точки зору другої особи» зазвичай називають тексти, у яких оповідач використовує займенник другої особи однини чи множини «ти / ви» як джерело надходження / походження точки зору, де на «ти» звертаються до героя, на відміну від читача, або наказовий спосіб дієслова, який передбачує звернення до когось. У західному літературознавстві оповідь із точки зору від другої особи вивчалася в розвідках М. Хопкинз [Hopkins 1981], Д. Ханцис [Hantzis, 1988], Д. Шофілда [Schofield, 1996], Б. Річардсона [Richardson, 1991], T. Брина [Breen, 1999], М. Дельконте [DelConte, 2003]. Автори вбачають переваги такого типу оповіді для досягнення унікального емоційного впливу на читача особливо в таких творах, де автор намагається передати травмувальний ефект якоїсь події в житті героя. Визначальною рисою такого типу оповіді, на думку Д. Ханціс, є те, що створюється враження інтерсуб'єктивності між автором, героєм та читачем. За допомогою точки зору від другої особи генерується модель зміщеної ідентифікації, що відрізняє іiї від першої та третьої особи, у яких суб’єкти мовлення є чітко ідентифікованими. На переконання Ханцис «This alternating pattern «continually places [the reader] in and continually displaces [the reader] from the 'you' while simultaneously placing and displacing others in and from the 'you'» [Hantzis 1988: 69]. Переключення між різними типами оповіді надає творові скерованого руху: читач одночасно втягується в 
текст зверненням «ти», і видаляється з тексту, що спричиняє зміну суб’єкту мовлення та звернення, яке неможливо з оповіддю від першої та третьої особи.

Мета цієї роботи - дослідити особливості змішаної композиції оповіді в романі Жауме Кабре «Я сповідуюся» (2011), яка складається із переключень між оповіддю від першої та третьої особи та перемежовується із оповіддю 3 точки зору від другої особи.

Композиція оповіді в романі «Я сповідуюся» відразу звертає на себе увагу, тому що являє собою дуже заплутану модель або краще сказати, відсутність будь-якої моделі, адже модель, за визначенням, передбачає можливість відтворення, наслідування, а у випадку 3 романом Кабре, це $\epsilon$ принципово неможливим. Композиція оповіді побудована за принципом нерівномірного чергування точок зору, що відображує відповідне світосприйняття головного героя, Адріа Ардевола, зумовлене станом його мисленнєвих процесів, порушених хворобою Альцгеймера. Адріа Ардевол, геніальний лінгвіст, мистецтвознавець та музикант, автор численних праць 3 естетики та філософії, у романі виступає і оповідачем ухудожненої версії власного дослідження історії скрипки Сторіоні, що зіграла неабияку роль у житті героя, і з якою безпосередньо пов'язане його дослідження природи зла у світі, і автором-розповідачем власної біографічної книги. Обидві оповіді інтегровані в такий спосіб, що інколи неможливо відчути межі цього сплетіння.

Із самого початку читач змушений шукати відповідь на питання: яка саме оповідь $є$ основною і яка $є$ тлом для розуміння подій основної оповіді; яка сюжетна лінія може вважатися провідною у творі, а яка функціонує вставною новелою: біографічні спогади головного героя, або історія створення, втрати, набуття та викрадення скрипки Сторіані, адже обидві історії представлені фрагментарно і розпорошені по всьому тексту. Первинна рамка не є цілісною, як не є цілісною вторинна рамка, до якої вводяться додаткові сюжети історії окремих родин та історії декількох поколінь родини головного героя. Якщо вважати за основну ту сюжетну лінію, яка є хронологічно довшою, то нею стає історія скрипки, яка почалася десь у XII ст., задовго до іï безпосереднього 
витворення майстром Сторіоні, тоді біографія героя стає одним 3 епізодів історії людей, які мали дотичне відношення до скрипки, які забезпечують читачеві необхідне тло для розуміння подій основної оповіді. Разом із цим, історія скрипки, що розповідається фрагментарно, функціонує як умовно вставна новела без необхідного обрамлення, оскільки містить у собі обов’язковий новелістичній елемент - пуант - неочікувану розв'язку в фіналі.

Особливістю композиції оповіді в романі «Я сповідуюся» $є$ постійне перемежовування типу оповіді, від першої або третьої особи, із вкрапленням досить незвичного типу «ти-оповіді», який будується на збігові фактичного джерела мовлення та суб'єкта мовлення.

Вибір типу оповіді від першої особи є доволі традиційним для біографії і обгрунтовується жанром сповіді, який є закріпленим у назві роману, на чому наголошується 3 першої сторінки: «B жанре, столь склонном ко лжи, как воспоминания, написанные для единственного читателя, я знаю, что не смогу не приврать, но буду стараться не очень присочинять. Все было именно так, и даже хуже. Я понимаю, что должен был рассказать тебе об этом давно, но это трудно, и даже теперь не знаю, с чего начать» [Кабре 2011 : 9]. Сповідний тон задається монологічною оповіддю з особистісними оцінками від першої особи, яка створює, враження щирості оповідача й емоційної достовірності. Сповідна тональність оповіді, що максимально дистанціює автора від читача, дозволяє автору розкрити внутрішній світ, емоції, переживання героя безпосередньо, не через авторські характеристики. У сповідальній манері герой, він же i автор книги спогадів, довіряє рядки не реальному співрозмовнику, а сторінкам паперу, власному літературному творові: «Я один на один с листом бумаги, и это мой последний шанс» [Кабре $2011: 9]$.

Перехід до оповіді від третьої особи, «усе знаючого оповідача» створює враження нейтральності, породжує ефект відстороненості, додає епічної дистанції. Такий тип оповіді забезпечує об'єктивний виклад думок, вчинків та життєвих обставин героя. На відміну від «я-оповіді» герой перетворюється із 
суб’єкта оповіді на об’єкт зображення. Отже, докорінно змінюється тональність оповіді, інтонація та кут зору. У свою чергу подекуди до обох типів оповіді вриваються фрагменти «ти-оповіді». Через форму «ти» суб’єкт мовлення звертається напряму до іншого героя, проте емоційне навантаження і подієве напруження передається безпосередньо читачеві: «Надеюсь, mы поймешь меня. Как поймешь и то, насколько беспомощным и одиноким я чувствовал себя $и$ как тосковал по тебе. Несмотря на расстояние, разделяющее нас, ты всегда служищь мне примером» [Кабре 2011 : 9].

Така композиція оповіді створює враження, що оповідачів нібито троє, а насправді один, який веде оповідь із різних точок зору - від себе, емоційно насичену, оповідь із залученням, відсторонену - від третьої особи та драматичну - 3 точки зору другої особи. Коливання між точками зору дозволяє авторові міцніше контролювати емоційну реакцію читача, ступінь його емоційної участі, підтягувати його ближче, або віддаляти від художнього світу твору.

Цікаво, що стилістично оповідачі ніяк не марковані, мовленнєві характеристики не різняться, тому відстежити зміну точки зору оповідача дуже важко. Стилістична однорідність мовця підтверджує припущення, що оповідач насправді один, але змінюється перспектива, 3 якої він описує події, його погляд.

Зміна точки зору при незмінному оповідачі дає можливість автору репрезентувати героя то як безпосереднього учасника події (оповідь від першої особи), то як стороннього свідка, який спостерігає за подіями в його житті або житті інших персонажів (оповідь від третьої особи), а то й героя-спостерігача за самим собою, нібито «чужими очима», як спосіб позбутися душевного болю від почуття провини за смерть коханої, яку він відчуває i про яку наполегливо нагадує читачеві протягом більшої частини книги: «Адриа посидел ещце несколько секунд перед телефоном. <..> На улище тихо шел снег. Он почувствовал себя в укрытии рядом с Сарой. Я почувствовал себя в укрытии рядом с тобой, Сара. Тогда было невозможно даже представить, что теперь, 
когда я пишу тебе, я буду жить открытый всем ветрам. ...» [Кабре 2011: 509] (Тут і далі напівжирний курсив наш. - Ш.М.).

Перевагою використання точки зору від другої особи вбачається в тому, що читач несподівано для себе опиняється безпосередньо пов'язаним з автором як джерелом мовлення i може відчувати себе більш тісно пов'язаним із персонажами та діями в романі, коли використовується звертання «ти». Читач, незалежно від свого бажання, залучається до емоційно-подієвої атмосфери твору: «Ты вошла в мою жизнь мягко, как и в первый раз, и я <..> думал только о твоем молчаливом и ободряющем присутствии. Адриа сказал ей: владей моим домом, владей мной» [Кабре 2011 : 424] .

Переключаючи тип мовлення на «ти» всередині одного мовця автор занурює читача в вир емоцій, що панують над носієм мовлення, буквально змушує його пережити ті самі почуття й емоції, якими зараз живе мовець. Прийом «ти-оповіді» вирізняється тим, що зближує читача 3 оповідачем, створює ілюзію повної достовірності, якщо не історичної, то емоційної та інтелектуальної, нібито читач стає безпосереднім учасником, свідком, чи навіть винуватцем подій або емоцій. Часта зміна форми оповіді і відповідно точок зору дає можливість авторові тримати емоційну дистанцію з читачем і запобігає виникненню кінцевого ототожнення себе з героєм. За допомогою переключення 3 однієї форми оповіді на іншу автор то наближує, то відсторонює читача, змінює інтонацію, тональність, запрошує читача до емоційного й інтелектуального поринання в ситуацію, програвання iї через свою психічну cфepy.

За обсягом фрагменти тексту, у яких чергуються форми оповіді та точки зору, є зовсім різними - від декількох сторінок до декількох абзаців, ніяк не розділених між собою. Максимальний стилістичний ефект ми отримуємо, коли така раптова зміна форм оповіді й точок зору відбувається в межах одного абзацу. Наприклад: «Градник хладнокровно следил в телескопический прицел за своей жертвой и думал: если ты нажмешь курок, Драго, то уже не попадешь в рай. Ты проживаешь цүелую жизнь с человеком, которого должен в конце 
конщов убить. Пот стекал градом со лба и мог бы замутить ему взгляд, но Драго усилием воли не допустил этого» [Кабре 2011 : 304]. Раптова зміна точки зору з третьої або першої особи на другу миттєво додає тексту драматизму, такого ефекту не дає ані перша, ані третя особа. Миттєве переключення на «ти» також миттєво чіпляє читача, немов автор і його втягує в подію.

Читати такий неоднорідний текст - це, звичайно, інтелектуальний виклик, до того ж паралельно з раптовим чергування форм оповіді відбуваються раптові часо-просторові зміни. Читач миттєво переноситься з XX сторіччя у XIII або XVII. За допомогою часопросторових перенесень автор розкриває й історію головного героя, й історію головного об'єкта - скрипки. Сприйняття часу в романі порушене через розірваність оповіді та відсутність будь-якої хронології. В одному абзаці, наприклад, співіснують час окупації Каталонії Гітлером та час панування середньовічної інквізиції: «Допросом руководил сам оберитурмбаннфюрер СС Адриан Хартбольд-Боск. Нельзя исключать возможность, что, несмотря на преклонный возраст, Лотар имел контакты с группой гнусного Герберта Баума. Но ведь он старик! (фра Микел) Дети и старики одинаково опасны для рейха. Так точно! (фра Микел) Вытрясите из него всю информаџию. Любыми средствами? Любыми средствами. Бейте его по пяткам для начала. Как долго? Пока трижды читается Ave Maria. A потом подержите на дыбе, пока единожды читается Credo in unuт Deuт. Слушаюсь, ваше преосвященство» [Кабре 2011 : 631]. Як видно з цього уривку, важко навіть визначити часову межу. Таких уривків, у яких спостерігаються миттєві, у межах одного абзацу, часопросторові переключення між добою панування фашизму в Європі та добою церковної інквізиції, доволі багато. Переключення часопростору в рамках одного типу оповіді створює ефект руху маятника, вічного повернення. За допомогою цього оповідного прийому автор доводить ідею непоборності та повторюваності зла й жорстокості в циклічній історії людства.

Можна навести численні приклади зміни часо-просторовових координат без зміни типу оповіді, як в епізоді торгів за скрипку між нацистськім лікарем із 
табору Аушвіц, штурмбаннфюрером Фойгом та батьком головного героя Феліксом Ардеволом: «В свою очередь, Хёсс просидел несколько дней в кабинете, пьтаясь просчитать, насколько вероятно, что этот ничтожный воришка и педик Ариберт Фойгт, кроме того, ещче и стукач. (1943-Аушвіц - М.Ш.)

- Пять тысяч долларов, синьор Фаленьями.

Человек с беспокойным взглядом уставился своими стеклянными глазами на Феликса Ардевола:

- Bbl надо мной издеваетесь?» [Кабре 2011 : 240] (приблизно1953 - «в кілометрі від Ватикану - Ш.М.» [Кабре 2011 : 241]). Вважаємо, що часопросторова організація твору варта особливої уваги та окремого ретельного дослідження.

Не можна стверджувати, що оповідь постійно переключається на мікрорівні одного абзацу. Змішана оповідь - чергування між першою та третьою особами - використовується автором для передання історії головного героя через спогади його життя: «Адриа не знал тогда, что два дня и одну почти полностью бессонную ночь Косериу не отрываясь читал экземпляр его диссертации, взятый у одного из членов совета. Я узнал это несколько лет спустя от самого доктора Каменека. Но в тот день Адриа просто застыл на месте в пустом коридоре» [Кабре 2011 : 334].

Проте до тексту інкорпоровані фрагменти 3 досить щільним переважанням однорідної оповіді від третьої особи, хоча жодна оповідь не вичерпується одним фрагментом, вона обов'язково продовжується в інших частинах роману, часто із порушенням хронології. Фрагменти являють собою художньо оброблені міні-сюжети, дотичні до двох ключових сюжетних ліній біографічної лінії головного героя та лінії скрипки. Зокрема доволі динамічними та однорідними $є$ епізоди, у яких розповідається про переховування, каяття та вбивство колишнього лікаря 3 Аушвіцу, що спокутував свою провину перед людством спочатку монахом, потім працюючи лікарем в одній із малорозвинених африканських країн 
[Кабре 2011 : 374-377, 475-480, 491-499]. Інша історія, оповідь про яку ведеться теж від третьої особи фрагментарно по всьому роману, дотична до християнської святині, медальйона із зображенням Діви Марії Пардакскої, що розпочалася до 1290 року і продовжувалася аж до 21 сторіччя [Кабре 2011 : 109; 163-164; 225; 352; 516-523]. Приклади можна продовжувати.

Окрім цього, численними є приклади з суцільним переважанням оповіді від першої особи. Скажімо, епізод про смерть матері героя. Передбачається, що така подія в житті людини повинна бути передана максимально емоційно, але в цьому випадку «я-оповідь» надає персонального відтінку події, проте не зрушує емоційний стан героя. Маркером зрушення емоційного та ментального стану як раз і стає мінлива оповідь.

Використання прийому миттєвого переключення 3 оповіді від третьої особи на першу або на оповідь із точки зору від другої особи не обмежується основною оповіддю, яка ведеться від імені Адріа Ардевола. Подібний прийом автор використовує в переказі епізодів із різних історичних епох, пов'язаних із природою зла. Показовою є історія порятунку з концтабору лікаря-єврея Хаїма, якому на диво вдалося вижити після участі в жорстокій розвазі офіцерів СС «полювання на зайців»: «Что он не выдержал и стал кричать фашистам, что они ублюдки, и самый трезвый из них рассмеялся и, прицелившись в самую молодую из оставшихся женщуин, крикнул: заткнись, или я всех их порешу! Ты замолчал. <..> Снаружи доносились раздраженные крики и торопливые приказы, которых Ты не мог понять. И оказалось, что назавтра начиналась эвакуация лагеря, потому что русские наступали быстрее, чем нацисты могли предположить, и в суматохе никто не вспомнил о шести или семи зайцах, сидевиих в узком дворе. Да здравствует Красная армия! - сказал ты по-русски, когда догадался, в чем дело, и одна из женщуин поняла его и перевела остальным. И тогда всхлипь умолкли, и появилась надежда. И так Ты удалось выжить» [Кабре 2011 : 438]. У наведеній цитаті «він» та «ти»є однією й тією ж особою, змінюється тільки точка зору оповіді. «Він» передає погляд збоку, із великої дистанції. 3 переключенням на «ти» точка зору концентрується на 
безпосередньому учасникові події, його внутрішній погляд концентрується на самому собі й відчутті неочікуваного порятунку, але й одночасно чіпляє читача, бо на «ти» можна звертатися до будь-кого, і читач потрапляє в емоційне коло героя, і відчуває те саме напруження, що й він. Однак займенник «ти» в наведеному уривку служить ще й для того, щоб створити враження приниження, позбавлення будь-якої ідентичності через позбавлення імені (Хаїм Епштейн), як і надання номерів в’язням концтаборів. Використання займенника «ти» створює зовсім дивний ефект злиття автора, героя й читача. Читач на деякий час стає героєм, тим, який біг від куль за життя, поглинається твором, зі спостерігача перетворюється на суб'єкта прямого звернення автора. Автор ставить читача на місце учасника подій і змушує пережити ті самі емоції, які доводяться переживати суб'єкту оповіді. Уже не герой, а нібито читач стає слухняним голосу автора, майже достеменно відтворює у своїй уяві та сприйнятті ситуацію 3 «ефектом присутності».

«Ти-фрагменти» тексту не можна ототожнювати 3 «невласне прямою мовою», хоч і зустрічаються вони в моменти найбільшої сповідальної напруги в тексті, коли головний герой немов звертається зі спогадами або каяттям до своєї коханої Сари, за смерть якої він відчуває провину. Для невласне прямої мови $\epsilon$ характерним заглиблення в думки героя, але відсутня адресність, спрямованість на іншу особу, як це відбувається з оповіддю 3 точки зору другої особи: «Ничто не сделало меня счастливым, кроме тебя, Сара, хотя ты больше всех заставила меня страдать» [Кабре 2011 : 509].

Якщо точки зору від першої і третьої особи покликані тримати читача на відстані, то точка зору від другої особи долає цю відчуженість і зміщує акцент на читача, особливо коли точка зору від другої особи першому рядку на початку глави. Перехід до наказового способу дієслова без використання прямої мови є маркером зміни точки зору на другу особу: «Не смотри на меня так» [Кабре 2011 : 37]. Адресатом цього звернення є автопортрет Сари, умовної співрозмовниці й адресата всієї сповіді життя Адріа Ардевола. Проте опосередковано сигнал про «незасудження» героя за його дії отримує читач. 
У наступному прикладі точка зору від другої особи силоміць спрямовує читача всередину того досвіду, через який доводиться проходити персонажу: «... Дюжина стрелков, как орль, заняли высотьл. Меткие стрелки получили винтовки системы Л. Нагана с телескопическим прицелом. А значит, ты на расстоянии вытянутой руки увидишь того, кого тебе предстоит убить, будешь наблюдать за ним, следить за каждым шагом - словом, установишь с ним связь [Кабре 2011 : 302]. Читач мимоволі занурюється в ситуацію, нібито перевдягається в шкіру того, кому ось-ось доведеться стріляти, тому що в нього немає іншого виходу. Ситуація, у яку потрапив герой, нав’язується читачеві, буквально всмоктує його до відцентрованої воронки, з якої немає порятунку. Читач позбавляється будь-яких опцій для вибору ступеня свого занурення. Ефект, отриманий від застосування точки зору від другої особи, коли читачеві диктують, що робити і як само відчувати, і Дел Конте і Ханціс порівнюють із триманням у заручниках [DelConte 2003 : 205; Hantzis 1988 : 105].

Використання точки зору, що змінюється всередині одного абзацу і без зміни фактичного мовця, викликане необхідністю підкреслити напругу в емоційному стані героя, як, наприклад, в епізоді зустрічі 3 коханою після довгих років розлучення: «С Эко под мышкой он открыл дверь и встретился с тобой, любовь моя, - ты стояла на лестничной площуадке, серьезная, держа в руках небольшую дорожную сумку; ты смотрела на меня своими темньми глазами, и в течение целой бесконечной минуты, словно окаменев, мы смотрели друг на друга: она - на площуадке, он - в квартире, держась за ручку открытой двери и пытаясь переварить это неожиданное событие. И в конце этой бесконечной минутьл ему пришло в голову сказать только: что тебе нужно, Сара. Я сам не могу в это поверить: единственное, что мне пришло в голову, это сказать: что тебе нужно, Сара?» [Кабре 2011 : 414].

У романі «Я сповідуюся» оповідь, у якій постійно змінюється точка зору, $\epsilon$ цілком передбачуваною для цього твору, набуває максимальної інтенсивності в останній третині, бо саме за допомогою цього прийому автор показує погіршення проявів симптоматики хвороби Альцгеймера, яка сильно пригнічує 
пам’ять та інші процеси в мозку. Про плутанину 3 хронологією мовець зазначає: «Приблизительно в это время... Кажется, я недавно об этом говорил. Какое значение может иметь хронологическая точность, если до сих пор я излагал события в таком беспорядке!» [Кабре 2011 : 451-2]. 3 розвитком хвороби прогресує і частотність звернення до різних точок зору в рамках одного оповідача. Прийом mingling narration - оповідь, що постійно змінюється, назвемо його так, має вражаючий ефект і створює унікальний світ тексту.

Запропоноване дослідження не претендує на вичерпність. Представлена розвідка $є$ лише первинним спостереженням, створеним під враженням цього неймовірно цікавого, неординарного, складного та великого за обсягом твору. Цілком припустимо, що композиція оповідних структур $є$ ще складнішою. Варто було б приділити більше уваги виявленню таких форм оповіді, як невласне пряма мова та невласне авторська мова, виявити відмінності та визначитися 3 функціями. Ми навмисне не розглядали таких адресатів висловлювання в романі, як ляльки: шериф Карсон, з Рокленду та Черний Орел, хоробрий вождь арапахо, «уявні» співрозмовники героя протягом усього твору, які заповнювали собою порожнечу в домі та самотність героя в дитинстві («дом не был предназначен для детей, равно как и моя семья» [Кабре 2011 : 37]), спричинену відсутністю любові в родині між його батьками і до свого єдиного сина («В нашем доме не ощупалось любви», «Мамы как бы не сущуествовало, а отец интересовался только своими торговыми операциями» [Кабре 2011 : 37]). Також поза нашою увагою залишилася оповідь у фрагментах тексту, де «яоповідачем» виступають інші мовці, відмінні від головного героя, а персонажі численних вставних історій, як, наприклад, партизан-снайпер, учасник антифашистського спротиву, у минулому священик Драго Градник, друг батька Адріа Ардевола [Кабре 2011 : 404-405].

Отже, змішаний і постійно змінюваний тип оповіді 3 використанням оповіді від другої особи є не дуже поширеним, але оригінальним і стилістично вишуканим типом побудови літературних текстів, що продемонстрував у композиції художнього мовлення роману «Я сповідуюся» Жаумо Кабре. 
Стилістичний ефект від використання оповіді від другої особи якісно відрізняється від окремого або почергового використання оповіді від першої або третьої особи. Успішне вплетення оповіді з точкою зору від другої особи додає емоційності та драматизму оповіді. Специфічний стилістичний ефект від цього типу оповіді наразі є недостатньо вивченим та неповністю оціненим. Сподіваємося, що, у міру поширення в художній літературі оповідних композицій із включенням точки зору від другої особи, дослідники приділять їй більше уваги та виведуть із периферії наукових досліджень у головне річище.

\section{БІБЛІОГРАФІЯ}

Кабре 2011 - Кабре, Жауме. Я сповідуюся. Москва : «Иностранка», 2011. $-727 \mathrm{c}$.

Breen, 1999 - Breene, Thomas E. «You : A Study of Second-person Narrative in Two Postmodern Novels» Dissertation. Ann Arbor : UMI, 1999. - 210 p.

DelConte 2003 - DelConte, Matt. «Why You Can’t Speak: Second-Person Narration, Voice, And A New Model For Understanding Narrative». Style 37.2, 2003. $-204 \mathrm{p}$.

Hantzis 1988 - Hantzis, Darlene Marie. "'You are about to begin reading': The Nature and Function of Second Person Point of View in Narrative». Dissertation Louisiana State University. Ann Arbor : UMI, 1988. - 194 p.

Hopkins 1981 - Hopkins, Mary Frances and Leon Perkins. «Second Person Point of View in Narrative» Critical Survey of Short Fiction ed. Frank N. Magill. New Jersey: Salem Press, Inc., 1981, pp. 119-32.

Schofield, 1996 - Schofield, Dennis. «The Second Person: A Point Of View?» Colloquy : Text Theory Critique 1, 1996.

Richardson, 1991- Richardson, Brian. «The Poetics and Politics of Second Person Narrative», Genre 24, 1991. pp. 309-330. 